\title{
Prosorhynchus Crucibulum (Digenea: Bucephalidae) Miracidium MoRphology AND ITS PASSIVE TRANSMISSION PATTERN
}

\author{
FRANCISCO C.J.*, HERMIDA M.A.* \& SANTOS M.J.*
}

\section{Summary:}

The characterization of Prosorhynchus crucibulum (Rudolphi, 1819) Odhner, 1905 egg and miracidium is important in order to better understand the transmission dynamics between the definitive host and the primary host, the mussel. In this way, the objective of this work was to study the miracidia morphology, in order to evaluate if this species belongs to the group of passive or active transmission larvae. The morphology of eggs is similar to the ones presented by other Prosorhynchus species, with a small size of $26 \times 17 \mu \mathrm{m}$, and four-five times smaller than the ones of Fasciola hepatica. The number of eggs produced per worm was around $6,760(4,236-8,401)$, which was four-five times higher than in F. hepatica. The miracidia presented small dimensions $24 \times 15 \mu \mathrm{m}$ (23-25 $\times 13-15 \mu \mathrm{m}$ range), a long stylet, two ciliated epithelial plates, very long cilia $(12.7 \mu \mathrm{m})$ and absence of terebratorium and eyespots. Those features of the miracidia suggest that $P$. crucibulum belongs to the group of passively infecting larvae.

KEY WORDS: Prosorhynchus crucibulum, egg, miracidia, transmission, morphology.

T he mussel (Mytilus spp.), a highly appreciated mollusc and therefore an important commercial species in southern Europe, is the first intermediate host of the bucephalid digenean Prosorbynchus crucibulum (Rudolphi, 1819) Odhner, 1905 (Matthews 1973, Cousteau et al., 1990; McGladdery et al., 1999). Moreover, Prosorbynchus sp. infection had been described as causing serious problems in mussel, like castration and weakening of the adductor muscle (Cousteau et al., 1990; Cousteau et al., 1993; Shelley et al., 1988; Lasiak, 1992; Calvo \& Mcquaid, 1998; Silva et al., 2002; Cochôa \& Magalhães, 2008; Francisco et al., 2010). Although there are some studies on the ecology, biology and morphology characteristics of adult and metacercariae of the genus Prosorbynchus Odhner, 1905 (Jones, 1943; Matthews, 1973; Santos \& Gibson, 2002; Laffargue et al., 2004; Etchegoin et al.,

\footnotetext{
* Universidade do Porto, Faculdade de Ciências, Departamento de Biologia, Rua do Campo Alegre, s/n., FC4, 4169-007 Porto, Portugal, and CIMAR Laboratório Associado / CIIMAR, Centro de Investigação Marinha e Ambiental, Rua dos Bragas, 289, 4050-123 Porto, Portugal.

Correspondence: Maria João Santos.

Tel.: 351220402805 - Fax: 351220402709 .

E-mail: mjsantos@fc.up.pt
}

Résumé : MORPHOLOGIE ET MODE DE TRANSMISSION PASSIVE DU MIRACIDIUM De PROSORHYNCHUS CRUCIBULUM (DIGENEA: BUCEPHALIDAE) La morphologie des œufs et du miracidium de Prosorhynchus crucibulum (Rudolphi, 1819) Odhner, 1905 est importante afin de mieux comprendre le mode de transmission entre l'hôte définitif et I'hôte intermédiaire, la moule. L'objectif de ce travail était d'étudier la morphologie du miracidium afin de savoir si l'espèce appartient au groupe des larves à transmission passive ou active. La morphologie des œufs est semblable à celle d'autres espèces de Prosorhynchus, avec une taille de $26 \times 17 \mu \mathrm{m}$, quatre-cinq fois plus petite que celle de Fasciola hepatica. Le nombre moyen d'œufs produits par ver est de 6760 (4 236-8 401), quatre-cinq fois plus élevé que celui observé avec $\mathrm{F}$. hepatica. Le miracidium est également de petite dimension, $24 \times 15$ um (23-25 × 13-15 um), avec un long stylet, les deux plans épithéliaux ciliés, des cils de dimension très longue $(12,7 \mu \mathrm{m})$ et l'absence de terebratorium et d'ocelle. Ces caractéristiques du miracidium de P. crucibulum suggèrent que l'espèce appartient au groupe des larves à infection passive.

MOTS-CLÉS : Prosorhynchus crucibulum, œuf, miracidium, transmission, morphologie.

2005; Bray \& Justine, 2006), information about the egg or miracidium stages and it life cycle dynamics are scantily presented. Recently, the miracidium active way of infection in Bucephalidae was questioned (Galaktionov \& Dobrovolskij, 2003). Therefore, the main aim of this work was to characterize the transmission of egg and/or miracidium P. crucibulum to the first host, and characterize the larva morphology comparing with Fasciola hepatica in order to classify them as passive or active miracidium.

\section{MATERIAL AND METHODS}



dult worms of $P$. crucibulum $(\mathrm{n}=14)$ were collected from four freshly caught conger eels (Conger conger), its definitive host. First, we used $P$. crucibulum $(\mathrm{n}=8)$, to estimate average number of eggs per adult worm. The number of eggs per adult from $F$. hepatica $(n=2)$ was also counted for comparison purposes.

The study of $P$. crucibulum egg and miracidium morphology was performed by light microscopy (LM), and the observations were made with a Zeiss Axiophot 
microscope, equipped with a digital camera Zeiss Axiocam Icc3 and image analysis software (AxioVision 4.6). The eggs were placed in a small drop of saline water (35\% salinity) on a slide and analysed. The live miracidia morphology was studied from eggs that were artificially hatched, by pressing them with a cover glass; some were observed fresh while others were later stained in methylene blue or eosin. The miracidium morphology of $F$. hepatica, an active infective larvae, was redrawn here for comparison purposes (Fig. 1) with our species.

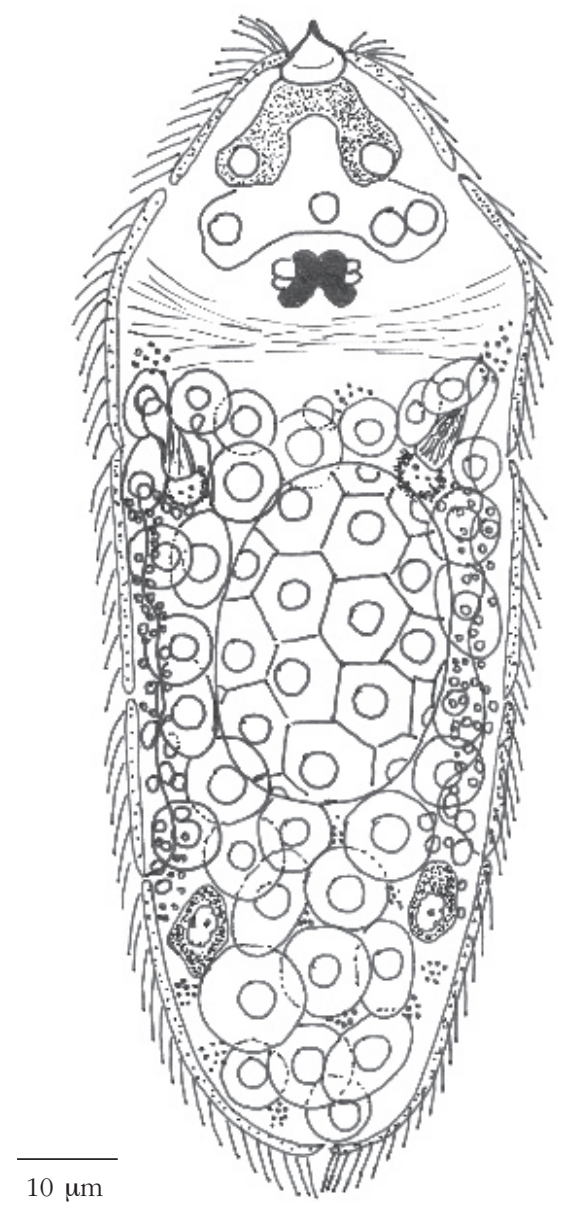

Fig. 1. - Miracidium of Fasciola hepatica (Linnaeus, 1758) redrawn and adapted from Kearn (1997).

\section{RESULTS}

The estimated average number of eggs per adult worm $(\mathrm{n}=8)$ in P. crucibulum was 6,760 $(4,236-8,401)$. The percentage and average number \pm standard deviation (range) of immature and mature eggs in the adult worms was $21 \%, 1,396$ (281$2,233)$ and $79 \%, 5,363(3,331-7,278)$, respectively. For comparison with our values we determined the same variables in $F$. hepatica. The minimum number of eggs $(\mathrm{n}=2)$ in adult worms of $F$. hepatica and its average number was 1,459 \pm 730 (296-1,163), presenting a ratio of young and mature eggs of $16 \%$ [114 \pm 59 (72-156)] and $84 \%$ [616 $\pm 554(224-1,007)]$.

The eggs from $P$. crucibulum $(\mathrm{n}=10)$ presented $26 \times 17 \mu \mathrm{m}$ in average size and $24-27 \times 11-20 \mu \mathrm{m}$ in range (Table I). The shell coloration of the eggs varied between transparent for the immature eggs and greenchestnut for the mature eggs.

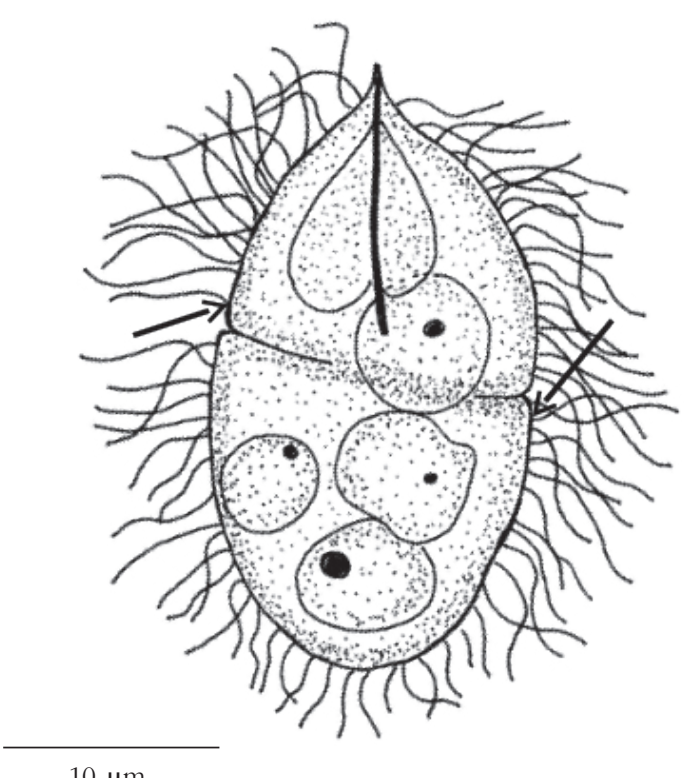

Fig. 2. - Drawing of a miracidium of Prosorbynchus crucibulum (Rudolphi, 1819) Odner, 1905, observed with light microscopy, covered with peripheral cilia and showing two epithelial plates (arrows) in the body.

\begin{tabular}{lccccc}
\hline Prosorbynchus species & Definitive host & Locality & n & Egg dimensions $(\boldsymbol{\mu m})$ & References \\
\hline P. crucibulum & Conger conger & Portugal & 8 & $26 \times 17$ & Present study \\
P. aculeatus & C. conger & Great Britain & - & $27 \times 18$ & Jones (1943) \\
P. maternus & Epinefilus malabaricus & New Caledonia & 8 & $28 \times 19$ & Bray \& Justine (2006) \\
P. pacificus & E. analogus & Mexico & 5 & $29-33 \times 19-20$ & Winter (1960) \\
P. pacificus & E. tauvina & Bay of Bengal & 3 & $32 \times 19$ & Bray \& Justine (2006) \\
P. pacificus & Mycteroperca olfax & Galapagos & 2 & $28-31 \times 15-16$ & Bray \& Justine (2006) \\
P. atlanticus & M. bonaci & Florida & 3 & $34 \times 19$ & Bray \& Justine (2006) \\
P. australis & C. orbignianus & Argentina & 14 & $32 \times 19$ & Bray \& Justine (2006) \\
\hline
\end{tabular}

Table I. - Measurements of Prosorhynchus spp. eggs. 
The miracidium from P. crucibulum (Fig. 2) measured $24 \times 15 \mu \mathrm{m}(23-25 \times 13-15 \mu \mathrm{m}$ range $)$, around five times shorter than $F$. hepatica. The cilia covered the whole surface of the body, arranged in two-row of epithelial plates, and not in several plates as in F. hepatica. A long cilia with 12.7 (11.8-13.7) $\mu \mathrm{m}$ in length. Stylet located outside of the apical gland. Terebratorium and eyespots absent. Four germinal cells and eight nucleus of somatic cells were also observed.

\section{DISCUSSION}

T $\mathrm{n}$ the Atlantic coast, two mussel species can serve as first intermediate host to P. crucibulum, they Lare Mytilus edulis and M. galloprovincialis (Matthews, 1973; Cousteau et al., 1990; Teia dos Santos \& Coimbra, 1995; McGladdery et al., 1999). Therefore, to study the trematode strategy for reaching the first intermediate host, it is relevant to understand the dynamics of its life cycle. P. crucibulum life cycle was studied by Matthews (1973), who also observed different stages of egg development (immature and mature) within the uterus of P. crucibulum, what is corroborated by the findings reported in our work. The percentage of each development stage was similar in P. crucibulum and $F$. hepatica. However, the minimum number of eggs/worm was different in both species, being higher in $P$. crucibulum than in $F$. hepatica, besides their different adult size (the former are 4-5 times smaller than the later). With regard to the dimensions of the eggs recorded here, we can see that they are similar to the ones recorded in other Prosorbynchus species, such as: P. aculeatus, P. maternus, P. pacificus, $P$. atlanticus and P. australis (Jones, 1943; Winter, 1960; Etchegoin et al., 2005; Bray \& Justine, 2006). However, they are not similar to the ones found in F. hepatica that are 4-5 times bigger (Duwel, 1982).

Therefore, we can note that P. crucibulum and $F$. bepatica have different strategies of egg production; the former has small eggs, and smaller miracidia, in large number, and the later has large eggs and larger miracidia in small number. This could be related to different strategies to achieve the first intermediate host, the mollusc.

The two strategies of the miracidium that are currently recognized in the literature are: some larvae have an active way of infection, while others have a passive way. According to Galaktionov \& Dobrovolskij (2003), these are associated with different morphologies of the larva. F. hepatica miracidium, which is an active infecting larva, presents a large size, an apical papilla, several ciliated epithelial plates and eyespots. While, in P. crucibulum miracidium we have reported several features that belong to the second group: small size, only two ciliated epithelial plates, terebratorium absent, stylet present and situated outside the apical gland and eyespots absent. In summary, we can say that the morphology of the miracidium from $P$. crucibulum is very simplified compared with that of $F$. hepatica. The same pattern was also recorded for $P$. squamatus and was associated to its passive way of infection (Galaktionov \& Dobrovolskij, 2003). The active infection of the first host for bucephalids, generally accepted, was questioned by those authors and is here confirmed by the reported features that they most probably have a passive way of infection.

\section{ACKNOWLEDGEMENTS}

This study was supported by CAPES (grant $\mathrm{n}^{\circ}$ I 37787-053) to C.J. Francisco, and to M.J. Santos (Project FCOMP-01-0124-FEDER-020726 / FCT-PTDC/ MAR/116838/2010).

\section{REFERENCES}

Bray A.R. \& Justine J.L. Prosorhynchus maternus sp. n. (Digenea: Bucephalidae) from the Malabar grouper Epinephelus malabaricus (Perciformes: Serranidae) of New Caledonia. Folia Parasitologica, 2006, 53, 181-188.

Cousteau C., Combes C., Maillard C., Renaud F. \& Delay B. Prosorbynchus squamatus (Trematoda) Parasitosis in the Mytilus edulis-Mytilus galloprovincialis complex: specificity and host-parasite relationships. Pathology in Marine Science, 1990, 291-298.

Cousteau C., Robbins I., Delay B., Renaud F. \& Mathieus M. The parasitic castration of the mussel Mytilus edulis by the trematode parasite Prosorbynchus squamatus: specificity and partial characterization of endogenous and parasiteinduced anti-mitotic activities. Comparative Biochemistry and Physiology, 1993, $104 \mathrm{~A}$ (2), 229-233.

Dickerman E.E. Paurorbynchus hidionts a new genus and species of trematoda (Bucephalidae, Paurorhynchinae n. subfam.) from the mooneye fishes Hiodon tergisus. Journal of Parasitology, 1954, 40, 311-315.

DFIWEL D. Unusually large eggs of a Fasciola hepatica strain. Z. Parasitenkd, 1982, 67, 121-124.

Etchegoin A.J., Timi T.J., Cremonte F. \& Lanfranchi L.N.A. Redescription of Prosorbynchus australis Szidat, 1961 (Digenea, Bucephalidae) parasitizing Conger orbignianus Valencienne, 1842 (Pisces, Congridae) from Argentina. Acta Parasitologica, 2005, 50 (2), 102-104.

Francisco C.J., Hermida M.A. \& Santos M.J. Parasites and Symbionts from Mytilus galloprovincialis (Lamark, 1819) (Bivalves: Mytilidae) of the Aveiro Estuary Portugal. Journal of Parasitology, 2010, 96 (1), 200-205. DOI: 10.1645/GE-2064.1. 
Galaktionov K.V. \& Dobrovolskij A.A. The biology and evolution of trematodes: an essay on the biology, morphology, life cycles, transmissions, and evolution of digenetic trematodes. Kluwer Academic Publishers, Netherlands, Boston, London, 2003.

Jones O.D. The anatomy of three digenetic trematodes, Skrjabiniella aculeatus (Odhner), Lecithochirium rufoviride (Rud.) and Sterrburus fusiformis (Lühe) from Conger conger (Linn). Parasitology, 1943, 35 (1-3), 40-57.

Kearn G.C. Parasitism and the platyhelminthes. Chapter $13-$ The biology of Fasciola bepatica. Springer, 1997, 297.

Laffargue P., Baudouin G., Sasal P., Arnaud C., Anras MarieLaure B. \& Lagardere F. Parasitic infection of sole Solea solea by Prosorbynchus spp. metacercariae (Digenea: Bucephalidae) in Atlantic nurseries under mussel cultivation influence. Disease of Aquatic Organisms, 2004, 58 (2-3), 179-184.

MatTHEws R.A. The life-cycle of Prosorbynchus crucibulum (Rudolphi, 1819) Odner, 1905, and a comparison of its cercaria with that of Prosorbynchus squamatus Odhner, 1905. Parasitology, 1973, 66, 133-164.

McGladdery S.E., StePhenson M.F. \& McArthur F. Prosorhynchus squamatus (Digenea: Platyhelminthes) infection of bleu mussels, Mytilus edulis, in Atlantic Canada. Journal of Shellfish Research, 1999, 18, 297 (Abstract).

SAnTos M.J. \& GiBson D.I. Morphological features of Prosorhynchus crucibulum and P. aculeatus (Digenea: Bucephalidae), intestinal parasites of Conger conger (Pisces: Congridae), elicited by scanning eletron microscopy. Folia Parasitologica, 2002, 49, 96-102.

Suloeva T.A. The patterns of organization of different phases of the bucephalids (Trematoda: Bucephalidae) life cycle. M.S. Thesis, St. Petersburg State University, St. Petersburg, Russia, 1999.

WOODHAED A.E. Life history studies on the trematode family Bucephalidae II. Transactions of the American Microscopical Society, 1930, 49, 1-17.

WinTer H.A. Algunos trematodos digenea de peces marinos de aguas del Oceano Pacifico del sur de California, USA y del litoral Mexicano. Anales del Instituto de Biologia, Universidad Nacional Autonoma de México, 1960, 183-208.

Received on April 26 ${ }^{\text {th }}, 2012$ Accepted on May $7^{\text {th }}, 2012$ 